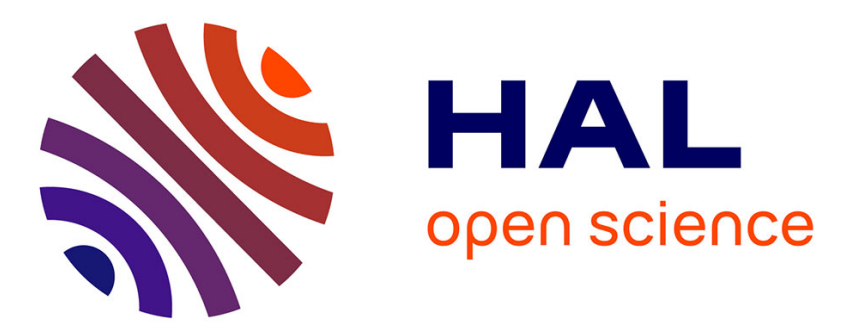

\title{
Efficacy of Silk Channel Injections with Insecticides for Management of Lepidoptera Pests of Sweet Corn
}

\author{
A. N. Sparks, Leslie Gadal, X. Ni
}

\section{To cite this version:}

A. N. Sparks, Leslie Gadal, X. Ni. Efficacy of Silk Channel Injections with Insecticides for Management of Lepidoptera Pests of Sweet Corn. Journal of Economic Entomology, 2015, 108 (4), pp.1869-1874. 10.1093/jee/tov113 . hal-01506469

\section{HAL Id: hal-01506469 \\ https://hal.science/hal-01506469}

Submitted on 3 Jun 2021

HAL is a multi-disciplinary open access archive for the deposit and dissemination of scientific research documents, whether they are published or not. The documents may come from teaching and research institutions in France or abroad, or from public or private research centers.
L'archive ouverte pluridisciplinaire HAL, est destinée au dépôt et à la diffusion de documents scientifiques de niveau recherche, publiés ou non, émanant des établissements d'enseignement et de recherche français ou étrangers, des laboratoires publics ou privés. 


\title{
Efficacy of Silk Channel Injections with Insecticides for Management of Lepidoptera Pests of Sweet Corn
}

\author{
A. N. SPARKS, JR., ${ }^{1,2}$ L. GADAL, ${ }^{3}$ AND X. $\mathrm{NI}^{4}$
}

\begin{abstract}
The primary Lepidoptera pests of sweet corn (Zea mays L. convar. saccharata) in Georgia are the corn earworm, Helicoverpa zea (Boddie), and the fall armyworm, Spodoptera frugiperda (J. E. Smith). Management of these pests typically requires multiple insecticide applications from first silking until harvest, with commercial growers frequently spraying daily. This level of insecticide use presents problems for small growers, particularly for "pick-your-own" operations. Injection of oil into the corn ear silk channel 5-8 days after silking initiation has been used to suppress damage by these insects. Initial work with this technique in Georgia provided poor results. Subsequently, a series of experiments was conducted to evaluate the efficacy of silk channel injections as an application methodology for insecticides. A single application of synthetic insecticide, at greatly reduced per acre rates compared with common foliar applications, provided excellent control of Lepidoptera insects attacking the ear tip and suppressed damage by sap beetles (Nitidulidae). While this methodology is labor-intensive, it requires a single application of insecticide at reduced rates applied $\sim 2 \mathrm{wk}$ prior to harvest, compared with potential daily applications at full rates up to the day of harvest with foliar insecticide applications. This methodology is not likely to eliminate the need for foliar applications because of other insect pests which do not enter through the silk channel or are not affected by the specific selective insecticide used in the silk channel injection, but would greatly reduce the number of applications required. This methodology may prove particularly useful for small acreage growers.
\end{abstract}

KEY WORDS sweet corn, corn earworm, Helicoverpa zea, insecticide

Sweet corn (Zea mays convar. saccharata) is the largest acreage vegetable crop in Georgia, averaging 10,376 ha (25,640 acres) annually from 2000 through 2008 (Boatright and McKissick 2009). In addition to large "commercial" growers, many smaller growers and "pick-your-own" producers include sweet corn in their mix of crops. The primary pests of sweet corn in Georgia are the corn earworm, Helicoverpa zea (Boddie), and the fall armyworm, Spodoptera frugiperda (J.E. Smith). Although fall armyworm can enter corn ears through the husks, the main concern with both of these pests is damage to the tip of the ear. Larvae generally gain access to the ear through the silk channel and then feed on the tip of the developing ear. Management with conventional foliar applied insecticides requires that these insects be killed prior to entering the protective environment of the silk channel. In commercial production in southern Georgia, this frequently requires $\geq 16$ applications from first silking to harvest. This insecticide-intensive approach provides numerous challenges for smaller growers, particularly for

\footnotetext{
${ }^{1}$ University of Georgia, Tifton Campus, Tifton, 2360 Rainwater Rd., Tifton, GA 31793.

${ }^{2}$ Corresponding author, e-mail: asparks@uga.edu.

${ }^{3}$ Institut National de la Recherche Agronomique, Montpellier, France.

${ }^{4}$ USDA-ARS, Crop Genetics and Breeding Research Unit, Tifton, GA.
}

"pick-your-own" operations. These growers frequently have small acreage sequential plantings of sweet corn in close proximity. The limited size of plantings, temporally staggered ear formation and need for ear protection, and the potential close proximity to human activity (picking) all present problems in an insecticide intensive management program.

Injection of mineral oil into the silk channel as an alternative management strategy was first developed in the 1930s (Barber 1938). This approach was reported to be limited by the characteristics of the husk, being more effective in corn ears with long, tight husks, and reported to be more efficacious with inclusion of a pyrethrum extract (Barber 1939, Pepper and Barber 1940). Timing of the application also affected efficacy and ear quality. Carruth (1942) indicated that applications made before completion of pollination caused a cessation or retardation in the development of the kernels (currently referred to as cone-tip), while applications made too long after pollination were less effective in preventing damage by corn earworm. Carruth (1942) refined this technique and reported a single application of $0.5 \mathrm{cc}$ of oil per ear applied at 5-7 d after silk emergence was as effective as two or three applications

More recent research with this technique focused on its potential use as an alternative to multiple foliar applications of synthetic insecticides, usually emphasizing potential use in organic production. The use of corn oil 
mixed with a Bacillus thuringiensis ssp. kurstaki (Bt) insecticide has generally provided increased ear protection over oil alone (Cook et al. 2003, Hazzard et al. 2003). Cook et al. (2003) reported corn oil plus Bt insecticide provided control of corn earworm for at least $17 \mathrm{~d}$ after application. Hazzard et al. (2003) indicated corn oil plus Bt insecticide provided significant but not always consistent corn ear protection. Cook et al. (2004) evaluated the timing of application on efficacy and cone-tip and suggested applications at $6-8 \mathrm{~d}$ after silk emergence.

Recent studies with corn oil injections, with and without Bt insecticide, for corn earworm management have shown poor results under the extreme pest pressure of South Georgia (A. N. S., unpublished data). However, it was theorized that placement of synthetic insecticides into the silk channel might provide adequate protection with a single application through the use of insecticides with extended residual activity and placement into the protective environment (no direct light) of the silk channel. Additionally, application of the silk channel injections at 5-7 d after silk growth initiation avoids issues related to rapid silk growth and nonprotected silk tissue at the ear tip. It was also theorized that use of water as a carrier, in place of the oil, might provide similar efficacy and avoid cone-tip injury associated with the oil injections. Therefore, the primary objective of these experiments was to evaluate the efficacy of oil and water injections into the silk channel as a delivery system for synthetic insecticides for management of ear-infesting Lepidoptera pests of sweet corn. Recent research in Georgia with Bt sweet corn has shown definite potential for damage to corn ears by sap beetles (Nitidulidae) when foliar applications of insecticides are eliminated during ear formation (A. N. S., unpublished data). Therefore, while management of caterpillar pests was the primary focus of this research, the injection treatments were also evaluated for effects on damage by sap beetles.

\section{Materials and Methods}

Studies were conducted in 2009 at the University of Georgia's Tifton Vegetable Park and at the Attapulgus Research and Education Center, in Tifton and Attapulgus, GA, respectively. All experimental plots were planted with a commercial sweet corn (var. Garrison, Syngenta Seeds, Boise, ID) and grown with standard production practices. No insecticides were applied in any experiment other than the designated silk injection treatments. Silk injections in all experiments were made in a total volume of carrier (corn oil or water) of $0.5 \mathrm{ml}$ per ear. Treatments in the initial experiment in Attapulgus were applied with the Zea-Later II (Johnny's Selected Seeds, Winslow, ME), which consists of a self-filling adjustable repeating pipette with a 3.8-cm-long needle designed for silk channel injection in corn. Injections in all other experiments were applied with a repeating pipette (Finnpipette II, Fisher Scientific, Pittsburgh, PA). For all injections, the tip of the pipette or needle was forced slightly into the silk channel $(\sim 1 \mathrm{~cm})$ to insure the treatment entered the channel. Mazola 100\% Corn Oil (ACH Food Companies, Memphis, TN) was used in all oil treatments in all experiments. All water treatments included an organosilicone surfactant (Silwet L-77 Surfactant, Helena Holding Company, Collierville, TN) at $0.05 \%$ by volume. Initial efforts with water without surfactant resulted in obvious loss of treatment resulting from the water repellency of the silks. Addition of the surfactant appeared to aid penetration into the silk channel. Rates of insecticides were calculated based on the assumption that 7.57 liters $(2$ gal.) of carrier would treat one acre of crop as indicated in the Zea-Later Owner's Manual; however, the actual rates per acre would vary with plant stand because treatments are applied on a per plant basis. Rates per 7.57 liters (two gal) of carrier tested in all but the rate experiment were $0.227 \mathrm{~kg}$ $(0.5 \mathrm{lb})$ of Dipel DF (B. t. subsp. kurstacki, Valent BioSciences Corporation, Libertyville, IL) and $29.6 \mathrm{ml}$ (one oz) of Spintor 2SC (spinosad, DOW AgroSciences LLC, Indianapolis, IN) and Coragen 1.67SC (chlorantraniliprole, I.E. du Pont de Nemours and Company, Wilmington, DE). The insecticides used in these studies were selected for potential safety to applicators and consumers. The rates represent a low labeled per acre broadcast rate for $\mathrm{Bt}$ and approximately one-third of the lowest labeled rate for the synthetic insecticides; however, these are being concentrated into very select sites (silk channel) within the field. The non-Bt insecticides were directly mixed in the carriers. Bt was directly mixed in the water carrier. For the oil plus Bt treatments, the $\mathrm{Bt}$ was first mixed in water $(1 / 10$ of the final volume) and then mixed with the oil.

Evaluations in all experiments consisted of rating damage by Lepidoptera larvae and sap beetles, and a rating for cone-tip injury. Lepidoptera larvae and sap beetle damage was rated separately on a 0 to 3 scale, with 0 , no damage; $1,1-4$ kernels at the tip of the ear damaged (kernels partially or completely consumed); 2 , significant tip damage (multiple kernels damaged) but $<2.54 \mathrm{~cm}$ down the ear and 3 , kernels damaged $>2.54 \mathrm{~cm}$ down the ear. Separation of Lepidoptera and sap beetle damage was determined by differences in appearance of damage, differences in frass, and presence of insects. Ears damaged by both pests were rated for both. Data presented for insect damage was summed for ratings of two and three as these ratings would represent nonmarketable ears in the fresh market. Cone-tip was rated on a similar 0 to 3 scale and data presented are summed for ratings of two and three as these would likely affect marketability.

The first experiment, conducted in Attapulgus, evaluated oil injection treatments with and without insecticides. The experiment was arranged as a randomized complete block design with four replications. Plots were four rows wide (on $0.9 \mathrm{~m}$ centers) by $7.62 \mathrm{~m}$, and all plants in the center two rows were treated. Only the primary (top) ear was treated on each plant. Treatments evaluated were corn oil alone, corn oil plus $\mathrm{Bt}$, corn oil plus spinosad, and corn oil plus chlorantraniliprole. A nontreated control was included for comparisons. Treatments were applied on 19 June $(\sim 5-8 \mathrm{~d}$ after $50 \%$ silking [the earliest date on which at least 
$50 \%$ of the plants had silks exposed]) and evaluated on 1 July. It was noted that some ears already contained corn earworm at the time of treatment. Twenty-five randomly selected ears were rated for damage in each plot as previously described.

Two similar experiments were conducted in Tifton to evaluate both oil and water as carriers for the silk injections. These experiments were conducted in sixteen row blocks of sweet corn at the Tifton Vegetable Park. Four blocks were established for each experiment with eight $15.24 \mathrm{~m}$ rows in each block and each experiment was conducted as a randomized complete block design. Each row within a block was randomly assigned a treatment and 22 randomly selected primary ears within each row were treated and tagged for later identification. In the first experiment, six injection treatments were evaluated as follows: oil alone, water (plus surfactant) alone, spinosad in each carrier, and chlorantraniliprole in each carrier. A Bt in oil treatment was not included. A nontreated control was included for a total of seven treatments. In the second experiment, eight injection treatments were evaluated: oil alone, water alone, and $\mathrm{Bt}$, spinosad and chlorantraniliprole in each carrier. These eight treatments were randomly assigned to rows in each block. Treatments in the first experiment were applied on 29 June ( $4 \mathrm{~d}$ after $50 \%$ silking) and evaluated on 13 July. Treatments in the second experiment were applied on 8 July ( $5 \mathrm{~d}$ after $50 \%$ silking) and evaluated on 17 July. Injections in these experiments were intentionally applied early within the recommended range of 5-7 d after silking to maximize efficacy against insects. The first 20 ears (of the 22 treated and tagged) found in each plot were evaluated as previously discussed. Twenty nontreated randomly selected ears were sampled across each experimental block in the second experiment as an indication of pest pressure.

Based on the efficacy of earlier treatments, it was believed that the silk injections with synthetic insecticides had the potential to be highly efficacious at rates lower than previously tested. Therefore, an experiment was conducted to evaluate various rates of spinosad and chlorantraniliprole in silk injections. Three rates of each insecticide were tested in oil as the carrier. The rates tested were $29.6,7.4$, and $1.85 \mathrm{ml}(1.0,0.25$, and $0.0625 \mathrm{oz}$ ) per 7.57 liters (2 gal.) of carrier. An oil injection and a nontreated control were included for comparisons. This experiment was conducted in a 16 row block at the Tifton Vegetable Park, with the eight treatments arranged in a randomized complete block with four replications similar to the two previous carrier experiments. Twenty-two randomly selected ears were treated in each row on 30 June and 20 ears were evaluated, as previously described on 14 July.

Data from replicated trials were evaluated with the PROC GLM procedure of PC-SAS (SAS Institute 2008, Cary, NC). All data were subjected to square root transformation prior to analyses. Where significant differences were indicated $(P<0.05)$ among treatments, means separations were conducted with LSD $(P=0.05)$. Data presented are for the combination of
Table 1. Ear damage in sweet corn treated with silk channel injections, Attapulgus, GA, 2009

\begin{tabular}{lccc}
\hline Treatment & \multicolumn{3}{c}{ No. ears with tip damage } \\
\cline { 2 - 4 } & $\begin{array}{c}\text { By } \\
\text { Lepidoptera }\end{array}$ & $\begin{array}{c}\text { By sap } \\
\text { beetles }\end{array}$ & $\begin{array}{c}\text { Cone-tip } \\
\text { injury }\end{array}$ \\
\hline Control & $13.1 \mathrm{a}$ & $23.2 \mathrm{a}$ & $1.2 \mathrm{c}$ \\
Oil & $14.1 \mathrm{a}$ & $22.0 \mathrm{a}$ & $3.4 \mathrm{bc}$ \\
Oil + Bt & $12.2 \mathrm{a}$ & $17.9 \mathrm{a}$ & $6.4 \mathrm{ab}$ \\
Oil + spinosad & $0.7 \mathrm{~b}$ & $6.9 \mathrm{~b}$ & $13.7 \mathrm{a}$ \\
Oil + chlorantraniliprole & $0.7 \mathrm{~b}$ & $4.6 \mathrm{~b}$ & $11.4 \mathrm{a}$ \\
$F$ & 14.43 & 25.76 & 7.88 \\
df & 4,12 & 4,12 & 4,12 \\
$P$ & 0.0002 & $<0.0001$ & 0.0023 \\
\hline
\end{tabular}

Data presented represent number of ears, of 25 sampled, with sufficient damage to rate as unmarketable. Numbers within columns followed by the same letter are not significantly different (LSD; $P=0.05)$.

ear damage ratings of two and three, as these categories represented unmarketable ears in the fresh market. Means presented were calculated from the transformed data means.

\section{Results}

Management of Lepidoptera Pests. Results from the experiment conducted in Attapulgus showed statistically significant reductions in ear damage by Lepidoptera larvae for both synthetic insecticides applied in oil (Table 1), with near elimination of this damage. The oil and oil plus Bt treatments did not reduce damage by Lepidoptera, as compared with the nontreated control.

In the two experiments with oil and water carriers, the synthetic insecticides provided statistically significant better control than the oil (Experiments 1 and 2) and oil plus Bt (Experiment 2) treatments (Table 2). The carrier (oil vs. water) did not significantly affect efficacy of the synthetic insecticide treatments in these experiments, with the exception of spinosad in Experiment 1 , which showed a statistically different but numerically minor increase in control with the oil injection. The apparent efficacy of the water plus Silwet injection, without insecticide, in the first experiment was not consistent. This treatment did not provide control in the second experiment nor in preliminary demonstrations with this technique (A. N. S., unpublished data).

In the rate experiment, all of the synthetic insecticide injections, with the exception of the lowest rate of spinosad, provided significantly better control than the oil injection (Table 3). With spinosad, the lowest rate allowed significantly more damage than the two higher rates, whereas all three rates of chlorantraniliprole performed statistically similar.

Sap Beetle Damage. Damage by sap beetles was generally not significantly affected by oil or oil plus Bt injection treatments, and showed relatively minor reductions when differences did occur (Tables 1-3). Addition of spinosad or chlorantraniliprole did provide significant reductions in damage by sap beetles across all experiments (Tables 1-3); however, with the possible 
Table 2. Ear tip damage in sweet corn treated with silk channel injections, Tifton, GA, 2009

\begin{tabular}{|c|c|c|c|c|c|c|}
\hline \multirow[t]{3}{*}{ Treatment $^{a}$} & \multicolumn{6}{|c|}{ No. of ears with tip damage } \\
\hline & \multicolumn{2}{|c|}{ By Lepidoptera } & \multicolumn{2}{|c|}{ By sap beetles } & \multicolumn{2}{|c|}{ Cone-tip injury } \\
\hline & Experiment 1 & Experiment 2 & Experiment 1 & Experiment 2 & Experiment 1 & Experiment 2 \\
\hline Control & $13.7 \mathrm{a}$ & 20.0 & $19.0 \mathrm{a}$ & 13.0 & $2.8 \mathrm{c}$ & 0.1 \\
\hline Water & $1.1 \mathrm{c}$ & $19.0 \mathrm{a}$ & $15.9 \mathrm{ab}$ & $9.7 \mathrm{ab}$ & $4.1 \mathrm{c}$ & $0.5 \mathrm{a}$ \\
\hline Oil & $4.4 \mathrm{~b}$ & $18.7 \mathrm{a}$ & $14.0 \mathrm{~b}$ & $8.8 \mathrm{ab}$ & $12.9 \mathrm{ab}$ & $2.1 \mathrm{a}$ \\
\hline Water $+\mathrm{Bt}$ & - & $13.0 \mathrm{~b}$ & - & $12.9 \mathrm{a}$ & - & $0.1 \mathrm{a}$ \\
\hline $\mathrm{Oil}+\mathrm{Bt}$ & - & $14.3 \mathrm{ab}$ & - & $5.2 \mathrm{bc}$ & - & $0.9 \mathrm{a}$ \\
\hline Water + spinosad & $1.0 \mathrm{c}$ & $3.4 \mathrm{c}$ & $5.0 \mathrm{~d}$ & $0.5 \mathrm{c}$ & $5.8 \mathrm{bc}$ & $0.1 \mathrm{a}$ \\
\hline Oil + spinosad & $0.0 \mathrm{~d}$ & $3.8 \mathrm{c}$ & $3.9 \mathrm{~d}$ & $0.1 \mathrm{c}$ & $16.5 \mathrm{a}$ & $4.1 \mathrm{a}$ \\
\hline Water + chlorantraniliprole & $0.1 \mathrm{~cd}$ & $1.8 \mathrm{c}$ & $8.4 \mathrm{c}$ & $0.7 \mathrm{~d}$ & $5.1 \mathrm{c}$ & $0.1 \mathrm{a}$ \\
\hline Oil + chlorantraniliprole & $0.0 \mathrm{~d}$ & $2.7 \mathrm{c}$ & $4.2 \mathrm{~d}$ & 1.1cd & $12.1 \mathrm{ab}$ & $2.4 \mathrm{a}$ \\
\hline$F$ & 18.98 & 36.65 & 46.85 & 8.57 & 5.02 & 2.11 \\
\hline df & 6,18 & 7,21 & 6,18 & 7,21 & 6,18 & 7,21 \\
\hline$P$ & $<0.0001$ & $<0.0001$ & $<0.0001$ & $<0.0001$ & 0.0035 & 0.0872 \\
\hline
\end{tabular}

Data presented represent number of ears, of 20 sampled, with sufficient damage to rate as unmarketable. Numbers within columns followed by the same letter are not significantly different (LSD; $P=0.05$ ).

${ }^{a}$ Control treatments were not randomized within experiment two and were not included in the statistical analyses; they are included as an indication of pest pressure. All treatments with water as the carrier included Silwet at $0.05 \%$ by volume.

Table 3. Effect of insecticide rates used in silk channel injections on ear damage in sweet corn, Tifton, GA, 2009

\begin{tabular}{llccc}
\hline Treatment $^{a}$ & $\begin{array}{c}\text { Rate per } 2 \\
\text { gal of oil }\end{array}$ & \multicolumn{3}{c}{ No. ears with tip damage } \\
\cline { 3 - 5 } & & $\begin{array}{c}\text { By } \\
\text { Lepidoptera }\end{array}$ & $\begin{array}{c}\text { By sap } \\
\text { beetles }\end{array}$ & $\begin{array}{c}\text { Cone-tip } \\
\text { injury }\end{array}$ \\
\hline Check & & $15.5 \mathrm{a}$ & $13.9 \mathrm{a}$ & $1.5 \mathrm{~b}$ \\
Oil & & $5.9 \mathrm{~b}$ & $13.7 \mathrm{a}$ & $11.3 \mathrm{a}$ \\
Spinosad & $0.0625 \mathrm{oz}$ & $3.4 \mathrm{~b}$ & $8.7 \mathrm{ab}$ & $9.3 \mathrm{a}$ \\
& $0.25 \mathrm{oz}$ & $0.6 \mathrm{c}$ & $4.0 \mathrm{bc}$ & $8.1 \mathrm{a}$ \\
Chlorantraniliprole & $0.0625 \mathrm{oz}$ & $0.5 \mathrm{c}$ & $6.5 \mathrm{bc}$ & $10.0 \mathrm{a}$ \\
& $0.25 \mathrm{oz}$ & $0.1 \mathrm{c}$ & $3.7 \mathrm{bc}$ & $10.9 \mathrm{a}$ \\
& $1.0 \mathrm{oz}$ & $0.0 \mathrm{c}$ & $5.0 \mathrm{bc}$ & $11.5 \mathrm{a}$ \\
$F$ & & 22.69 & 4.55 & 3.88 \\
$\mathrm{df}$ & & 7,21 & 7,21 & 7,21 \\
$P$ & & $<0.0001$ & 0.0032 & 0.0073 \\
\hline
\end{tabular}

Data presented represent number of ears, of 25 sampled, with sufficient damage to rate as unmarketable. Numbers within columns followed by the same letter are not significantly different (LSD; $P=0.05$ ).

${ }^{a}$ Spinosad and chlorantraniliprole treatments were applied in oil.

exception of the second carrier experiment (Table 2), the level of control of sap beetle damage was not commercially acceptable in any treatment.

Cone-tip Injury. Cone-tip symptoms can result from factors other than silk injections (Nielsen 2003) and did appear in the nontreated controls in all of the replicated experiments. In the experiment in Attapulgus, oil alone tended to increase cone-tip injury as compared with the control but it was not statistically significant (Table 1). Addition of insecticide, particularly synthetic insecticides, increased the incidence of cone-tip in this experiment. However, in the rate experiment, all of the treatments with oil caused a similar level of cone-tip injury (Table 3 ).

In the first experiment comparing carriers, treatments containing oil significantly increased incidence of cone-tip injury (Table 2). In the second experiment, cone-tip injury occurred at a lower level and differences were not significant, but numerical trends were identical to the first experiment. Use of water plus surfactant appeared to reduce the potential for cone-tip injury in both experiments.

\section{Discussion}

These experiments indicated that silk injections with insecticides can be highly efficacious for management of Lepidoptera pests attempting to enter the ear through the silk channel in sweet corn. Oil and oil plus Bt silk injections were inconsistent in control, as previously reported by Hazzard et al. (2003). Reasons for this inconsistency are not known; however, portions of the inconsistency may be related to timing of application. Results with oil alone injections were poorest in the Attapulgus experiment in which treatments were applied relatively late within the recommended timeframe of $5-7 \mathrm{~d}$ after $50 \%$ silking. Inclusion of a synthetic insecticide greatly enhanced control and consistency of silk channel injections. Further, performance was similar even when applied late within the application timing range, suggesting that timing of application may not be as sensitive with the synthetic insecticides. For control of Lepidoptera larvae, the two insecticides tested provided excellent control at rates well below the labeled rates. The labeled rates for foliar applications for corn earworm control on sweet corn for Spintor and Coragen are 219 to $438 \mathrm{ml} / \mathrm{ha}$ ( 3 to 6 $\mathrm{oz} / \mathrm{acre}$ ) and 256 to $365 \mathrm{ml} / \mathrm{ha}$ ( 3.5 to 5 oz/acre), respectively. The actual rate per hectare used with silk injections would vary with plant density because treatments are applied on a per plant basis; however, with even a relatively high plant density $(26,000$ per acre) silk injection would utilize approximately 12.8 liter (3.4 gal) of solution per acre. The rate experiment indicated excellent control with both synthetic insecticides at $14.78 \mathrm{ml}(0.5 \mathrm{oz})$ per 7.57 liter ( $2 \mathrm{gal})$, with a single application applied $\geq 10 \mathrm{~d}$ prior to harvest. This rate 
equates to less than one-third of the lowest broadcast rate for these insecticides. In addition, multiple applications are necessary for control with conventional foliar applications, with applications allowed up to $1 \mathrm{~d}$ prior to harvest. While lower than labeled rate applications are legal, the legality of the silk channel injections may be questioned as this places insecticides in a protected environment, concentrates insecticides in a specific location as compared with broadcast foliar applications, and potentially places the insecticide in greater contact with the edible kernels. However, this application technique is not prohibited by current labels and apparently has not been questioned for use with Bt insecticides. Resistance management recommendations generally recommend against use of less than labeled rates of insecticides; however, this is generally in the context of broadcast applications where reduced rates can easily result in reduced mortality of targeted insects. Silk channel injections have shown to provide excellent protection of ears at these reduced rates and would provide in-field refugia through nontreated secondary ears.

This approach would not likely eliminate the need for conventional foliar insecticide use in sweet corn production. Additional insecticide applications would likely be required in some cases for fall armyworm and other Lepidoptera pests that can attack ears via routes other than the silk channel (Nuessly and Webb 2015). In addition, research with Bt sweet corn in south Georgia has clearly demonstrated the emergence of additional insect pests (e.g., sap beetles, silk fly, and stink bugs) when the typical reliance on foliar insecticides is removed (A. N. S., unpublished data). While the silk channel injections did provide some suppression of sap beetle damage, the level of control generally experienced in these experiments would not have been commercially acceptable. This was expected, as the insecticides used are selective and primarily recommended for Lepidoptera pests (CDMS 2015). Silk channel injections, with the proper insecticide, might control sap beetles and silk fly, as they tend to enter through the silk channel (Nuessly and Webb 2015), but would likely have no impact on stink bugs, which can feed directly through the husk (Capinera 2001). Based on research with Bt sweet corn in south Georgia, it is likely that up to three or four foliar insecticide applications may be needed to provide protection from these other insects and routes of injury (A. N. S., unpublished data).

While these studies indicated excellent control with water plus a surfactant as the carrier for the synthetic insecticides, additional studies are needed to verify the consistency of this approach and to verify the reduced potential for cone-tip injury. If water can be used as the carrier, and does not have the same potential for cone tip injury, treatments could be applied earlier in the silking period. This could result in improved efficacy in ear protection, as Cook et al. (2004) indicated, a linear decrease in marketability as applications of oil plus Bt were delayed from 3 to $11 \mathrm{~d}$ after silking.
The two insecticides used in these studies were selected for potential safety to applicators and consumers (CDMS 2015). Neither of these is approved for organic production; however, Entrust (a formulation of spinosad) is approved for organic production (Organic Materials Review Institute [OMRI] 2015) and should provide similar efficacy. Additional experiments to evaluate other potential insecticides, both organically approved and those not so designated, for this approach are needed to identify promising products, appropriate rates, and potential efficacy against nonLepidoptera pests.

Silk channel injections are a labor-intensive approach to pest management, with Hazzard and Westgate (2005) indicating $8-10 \mathrm{~h}$ are required to treat an acre of sweet corn when using the Zea-Later II applicator. Thus the labor costs are high, however, this technique allows for a single application to replace the majority of 16 or more foliar sprays necessary under the extreme pest pressure of fall production in the southeast United States. This reduced reliance on foliar sprays would prove especially beneficial to small acreage growers and "pick-your-own" operations. These growers frequently have sequential plantings of small acreages that make insecticide intensive management difficult to conduct and difficult to coordinate with harvest activities which may involve the general public. Silk channel injections for insect management may provide an exceptional alternative approach for these sweet corn producers.

\section{Acknowledgments}

The help of Mike Beggs, Andrew Dickson, and Melissa Knape in production of the crops in Tifton and evaluation of the experiments was greatly appreciated. The aid of Billy Mills and the entire field crew at the Attapulgus Research and Education Center also was appreciated.

\section{References Cited}

Barber, G. W. 1938. New control methods for the corn earworm. J. Econ. Entomol. 31: 459.

Barber, G. W. 1939. The use if insecticides in light mineral oil for corn ear worm control. J. Econ. Entomol. 32: 598.

Capinera, J. L. 2001. Handbook of vegetable pests. Academic Press, San Diego, CA

Carruth, L. A. 1942. An investigation of the mineral oil treatment for corn earworm control. J. Econ. Entomol. 35: 227-233.

CDMS. 2015. Spintor and Coragen labels and MSDS sheets. (http://www.cdms.net/LabelsMsds/LMDefault. aspx?t) (accessed 30 April 2015).

Cook, R., A. Carter, P. Westgate, and R. Hazzard. 2003. Direct silk applications of corn oil and Bacillus thuringiensis as a barrier to corn earworm larvae in sweet corn. HortTechnology 13: 509-514.

Cook, R., A. Carter, P. Westgate, and R. Hazzard. 2004. Optimum timing of an application of corn oil and Bacillus thuringiensis to control Lepidopteran pests in sweet corn. HortTechnology 14: 307-314.

Hazzard, R., and P. Westgate. 2005. Organic insect management in sweet corn. SARE Fact Sheet 01AGI2005. $11 \mathrm{pp}$. 
Hazzard, R. V., B. B. Schultz, E. Groden, E. D. Ngollo, and E. Seidlecki. 2003. Evaluation of oils and microbial pathogens for control of Lepidopteran pests of sweet corn in New England. J. Econ. Entomol. 96: 1653-1661.

Nielsen, R. L. 2003. Tip fill problems in corn. (http://www.kingcorn.org/news/articles.03/TipFill-0917.html) (accessed 30 April 2015)

Nuessly, G. S., and S. E. Webb. 2015. Insect management for sweet corn, p. 18. U. of Florida IFAS Extension Pub. ENY-472
(OMRI) Organic Materials Review Institute. 2015. OMRI products list. (http://www.omri.org/about-productslist) (accessed 30 April 2015)

Pepper, B. B., and G. W. Barber. 1940. Dichloroethyl ether in mineral oil for corn earworm control in sweet corn. J. Econ. Entomol. 33: 584.

SAS Institute. 2008. SAS Enterprise Guide version 4.2. SAS Institute, Cary, NC. 